\section{BER}

Bureau for

Economic Research
Department of

Economics

University of Stellenbosch

\title{
CHANGING PATTERNS OF SOUTH AFRICAN INCOME DISTRIBUTION: TOWARDS TIME SERIES ESTIMATES OF DISTRIBUTION AND POVERTY
}

ServaAs van der Berg \& Megan Louw

Stellenbosch $E_{\text {conomic }} W_{\text {orking }} \mathrm{P}_{\text {apers : }} 2$ / 2003 


\section{BER}

Bureau for

Economic Research
Department of

Economics

University of Stellenbosch

\section{CHANGING PATTERNS OF SOUTH AFRICAN INCOME DISTRIBUTION: TOWARDS TIME SERIES ESTIMATES OF DISTRIBUTION AND POVERTY}

SERVAaS VAN DER BERg \& Megan LouW

Stellenbosch Economic $W_{\text {orking }} \mathrm{P}_{\text {apers : }} 2$ / 2003

Servaas van der Berg \& Megan Louw

Department of Economic

University of Stellenbosch

E-Mail: SvdB@sun.ac.za; 13223925@sun.ac.za 


\title{
Changing PATTERNS OF SOUTH AFRICAN INCOME DISTRIBUTION: TOWARDS TIME SERIES ESTIMATES OF DISTRIBUTION AND POVERTY
}

\author{
SERVAAS VAN DER BERG \& MEgAN LOUW
}

\begin{abstract}
Research on income distribution in South Africa has, for obvious reasons, focused on inter-racial (inter-group) income distribution. Quite dramatic changes have occurred in inter-racial income distribution patterns since the 1970s, with the black share of income rising for the first time and at times exceeding the rise in their population share. This implies a narrowing inter-racial income gap.

Data on income distribution remain scarce, so that it remains difficult to obtain the full picture about changes in income distribution. In particular, widening inequality within the black population has received much attention. Rises in black unemployment and in black wages have had inequality-inducing effects on black incomes. Is maldistribution of income between races now making way for maldistribution of income within race groups? Put differently, is inequality shifting from inter-group to intra-group inequality (from between group to within group inequality)?

This paper pieces together information from various sources of data (censuses, household surveys, marketing surveys, published wage data series, etc.) to inform estimates of inter- and intra-group distribution over a longer time frame, in an effort to improve analysis of income inequality and poverty trends. These income distribution patterns also have considerable implications for the growth and evolution of the South African consumer market.
\end{abstract}

\section{J EL classification: D31, D33, D63, E25, C81, J 3, $O 1$}




\title{
CHANGING PATTERNS OF SOUTH AFRICAN INCOME DISTRIBUTION: TOWARDS TIME SERIES ESTIMATES OF DISTRIBUTION AND POVERTY
}

\author{
SERVAAs VAN DER BERG \& MEgAN LouW
}

\section{INTRODUCTION}

The heated debate about trends in post-transition racial distribution of income, inequality and poverty has been fed by different perspectives on the policy path followed by the new government, particularly regarding its economic and distributive policies. Unfortunately, this debate has floundered because of uncertain trends in post-transition income, mainly for reasons of poor quality of information. This can be related to the fact that much of our distribution data comes from surveys and censuses, which are in many respects poor information sources - they take place only intermittently, there is poor comparability between different surveys and censuses, the data is subject to long time lags before it becomes available, and results are usually incompatible with National Accounts trends or are not made to be compatible with National Accounts by those who interpret them.

One of the main areas of contention regarding post-transition trends relates to whether poverty has increased or decreased. Confusion was fed by the release of the IES2000 (the Income and Expenditure Survey 2000 conducted by Statistics South Africa) and in particular by a publication by Statistics South Africa (StatsSA 2002) comparing the results of this survey with the IES1995. This comparison concluded that real incomes in South Africa have been declining between 1995 and 2000 - contrary to all national accounts and demographic statistics also compiled by StatsSA -, that racial income distribution has worsened and that poverty has substantially increased. However, Statistics South Africa has since admitted that this survey is not comparable with the IES1995. ${ }^{1}$ Terreblanche (2002: 423) even suggests that poverty has worsened since 1970, but this is clearly at odds with all empirical observations.

Despite the uncertainty surrounding analysis of recent trends in poverty, there is greater agreement over patterns in inequality. During the early 1970s the previously constant racial shares of income started changing in favour of blacks, at the expense of the white share of income (McGrath 1983). At that stage, disparities in the distribution of income across race groups underlay South Africa's characteristically high Gini coefficient. But while inter-racial inequality continued to decline throughout the eighties and nineties

\footnotetext{
${ }^{1}$ Those working on the IES2000 have found it to be an exceedingly poor data set, with evidence of sloppy fieldwork, coding and management of data. For instance, grain expenditure is double counted in total food expenditure and in total expenditure. About $25 \%$ of records are useless for many purposes, for instance because recorded food expenditure is zero, or because total expenditure and total income (after allowing for savings and dissaving) differ by more than $30 \%$.
} 
(Simkins 1991, Whiteford \& Van Seventer 2000), inequality within race groups particularly within the black group - increased. Whiteford and Van Seventer (2000:19) find that from 1991 to 1996 the incomes of the poorest 40 percent of black households dropped by more than 20 per cent, while the wealthiest 10 percent of black households experienced increases in income of almost the same magnitude. These authors explain this in terms of changing employment patterns: white employment showed the largest decline during the period, and, while black employment figures also reflected a downward trend, there was a rise in the number of blacks employed in skilled jobs coupled with increasing mean wages for this group of workers. In light of the fact that wages are currently responsible for approximately two thirds of the variation in household income, it is unsurprising that the highest level of inequality per population group is emerging amongst blacks (Leibbrandt, Woolard \& Bhorat 2000: 40, 48). The driver of overall inequality in South Africa has thus changed: it was estimated that by 1996 a striking 67 per cent of overall inequality in South Africa was due to within group dispersion of income (Whiteford and Van Seventer 2000: 28). A fairly static level of overall income inequality consequently masks this phenomenon of rising intra-racial inequality, countered by declining inter-racial earnings variation (Moll 2000).

This paper attempts to provide alternative estimates of income distribution in South Africa, utilizing data that allow us to evaluate income distribution across time, reducing dependence on the vagaries associated with individual surveys. In particular, we attempt to arrive at racial distribution data as well as data on inequality within race groups, which we then combine to arrive at estimates of overall poverty from 1970 to 2000 . However, data for the last few years of this period is suspected to be less reliable than data for the earlier part, thus we purposely choose conservative assumptions to arrive at what we shall refer to as our standard or pessimistic estimates for this period, so that we can be fairly certain that these estimates are worst case estimates of poverty trends after 1995. An alternative, less pessimistic estimate is also shown for 2000.

The paper is set out as follows:

- in the next section we discuss the methodology in broad terms;

- thereafter we look at the results of applying this methodology in terms of the inter-racial (between group) distribution of income;

- then we apply the intra-racial (within group) distribution data to the inter-racial distribution data sets, in order to arrive at overall estimates of inequality and poverty;

- next we discuss the trends in poverty as derived from our data, whilst continually also pointing out the deficiencies and uncertainties in this data; and finally

- in our conclusion we provide some comments about underlying trends ascertainable from these estimates and what these imply for the income distribution debate.

\section{METHODOLOGY}

The methodology utilized here consists in the main of:

- decomposing current income from the national accounts into its three major components; 
- estimating the racial distribution and trends therein for these components from alternative sources of information;

- applying data for distributions within race groups obtained intermittently through censuses and surveys to these results; and then

- interpolating or forecasting for the rest of the period.

Using a combination of national accounts data for estimates of mean income and survey data for distribution estimates is a methodology similar to that employed by Sala-i-Martin (2002a; 2002b), Quah (2002) ${ }^{2}$ and Bourguignon \& Morrisson (2002), and in more controversial fashion also by Bhalla (2002), to derive estimates of world income distribution and poverty trends.

The rationale for combining these data sources is that the (often increasing) discrepancy between national accounts data and survey data has cast doubt on poverty trends derived exclusively from surveys (see e.g. Deaton 2001). This methodology has, however, been criticised by Ravallion $(2001 ; 2002)$ and by Deaton $(2003 ; 2001)$. They argue that the validity of this approach requires a very strong and unlikely assumption that survey underestimation of actual income is distribution-neutral, i.e. that the income of the rich and the poor is underestimated to the same degree. However valid their criticism may be, this leaves no way of dealing with inequality where surveys clearly underestimates incomes (as is the case in South Africa), other than waiting for more perfect surveys, because their argument implicitly acknowledges that distributional data from surveys cannot be trusted. If one accepts that surveys underestimate mean incomes but nevertheless require distributional data, there is little option but to combine national accounts and surveys data sources. Fortunately, income distribution is slow-moving, thus distributional changes seldom drive aggregate poverty results in the presence of strong economic growth, as Quah (2002: Technical notes) illustrates. He shows that only in very extreme cases would it be likely that growing inequality could prevent strong economic growth from reducing poverty.

Current income, the concept closest to the former personal income used in the national accounts, consists of three major components, viz. remuneration, state transfers and income from property. ${ }^{3}$ Figure 1 shows the composition of current income from 1970 to the year 2000. It is evident that the share of income from property has risen substantially since 1980, mainly at the expense of remuneration income. To the extent that the affluent tend to have both larger asset holdings and higher skill levels, they would have benefited most from property yields and have been relatively immune to labour market conditions, in direct contrast with the poor, who are often unskilled and have been most affected by rising unemployment. Note that there has been substantial real per capita growth in income and in each of the income components since 1970, and growth of current income per capita for the contentious $1995-2000$ period has been a healthy $3.4 \%$ per annum since

\footnotetext{
${ }^{2}$ See especially the Technical Notes on the methodology of such estimates.

${ }^{3}$ There are also some minor components, but these are so small that they can safely be ignored for present purposes and just subsumed under income from property. Strictly speaking, personal income proper is over-estimated, because income of institutions offering services to the household sector (such as welfare and church organisations) are also included, but this has a very minor impact on both the level and the trend of these magnitudes.
} 
the mid-1990s, implying that a considerable increase in inequality would have had to occur in order to raise the poverty headcount ratio.

\section{Figure 1:}

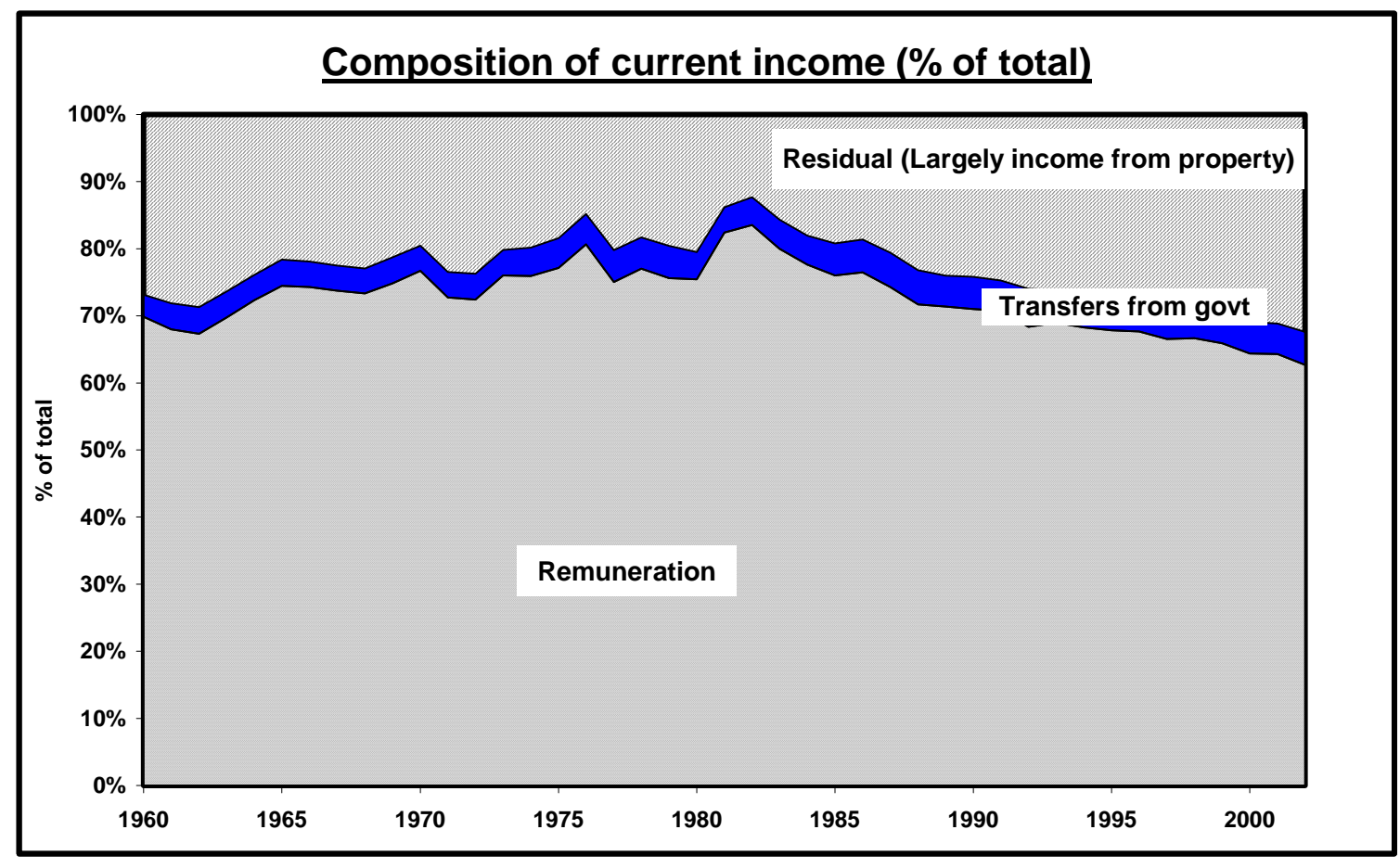

\section{ESTIMATING INTER-RACIAL (BETWEEN GROUP) DISTRIBUTION OF INCOME}

The method we follow for arriving at inter-racial income distribution estimates decomposing current income into its three major components and analysing trends in each of these - has earlier been utilised by Van der Berg (1986; 1987; 1989a \& b) for forecasting inter-racial income distribution.

To estimate the racial distribution of remuneration, we turn to two sets of data from official sources. The first relates to the distribution of formal employment by race contained in the Standardised Employment Series, available only up to $1996 .{ }^{4}$ Combining this with average wages paid to the different groups allows us to derive the distribution of remuneration income by race group by simply multiplying employment and relative wages for each group and applying the proportions of the total obtained in this manner for each race group to total remuneration income (compensation) in the National Accounts data. However, wage movements in the primary and non-primary sector differed somewhat in the 1970s, due to the effect of strong mining unions and gold price movements on unskilled mining wages. Furthermore, from 1984 on racial wage levels in

\footnotetext{
${ }^{4}$ This series was originally drawn up by Roukens de Lange and Van Eeghen $(1984 ; 1990)$ for the Institute of Futures Studies at the University of Stellenbosch, and then later updated and published by Statistics South Africa. Klaasen \& Woolard (1999) provide a good overview of the sources of employment and unemployment statistics and are quite critical of the Standardised Employment Series. However, it was clearly the best source for our purposes as it provides consistent and racially decomposed estimates of formal employment, which we require for estimating the distribution of remuneration income.
} 
the primary sector were no longer published. For these reasons we separated primary from non-primary remuneration. Using the sectoral decomposition of the remuneration component of current income kindly provided by the SA Reserve Bank, we calculated the distribution of both primary and non-primary remuneration separately in the manner described above. From 1984 onwards, however, we assumed that relative wage movements (rather than levels) by race in the non-primary sectors were mirrored in the primary sector. Estimates beyond 1996 are based on a combination of extending trends and various bits of official data containing race-based information, including the various October Household Surveys and Labour Force Surveys. Incompatibility in the methods and definitions used, however, make these surveys far from ideal sources for comparison purposes, as other researchers have already documented (e.g. Bhorat 2003a).

Our results for remuneration, i.e. the wage bill, are set out in Figure 2. It is apparent that black remuneration has been increasing throughout this period (despite ongoing job losses that affect less skilled workers), whilst visually it is not equally clear that the same observation can be drawn for other groups.

\section{Figure 2:}

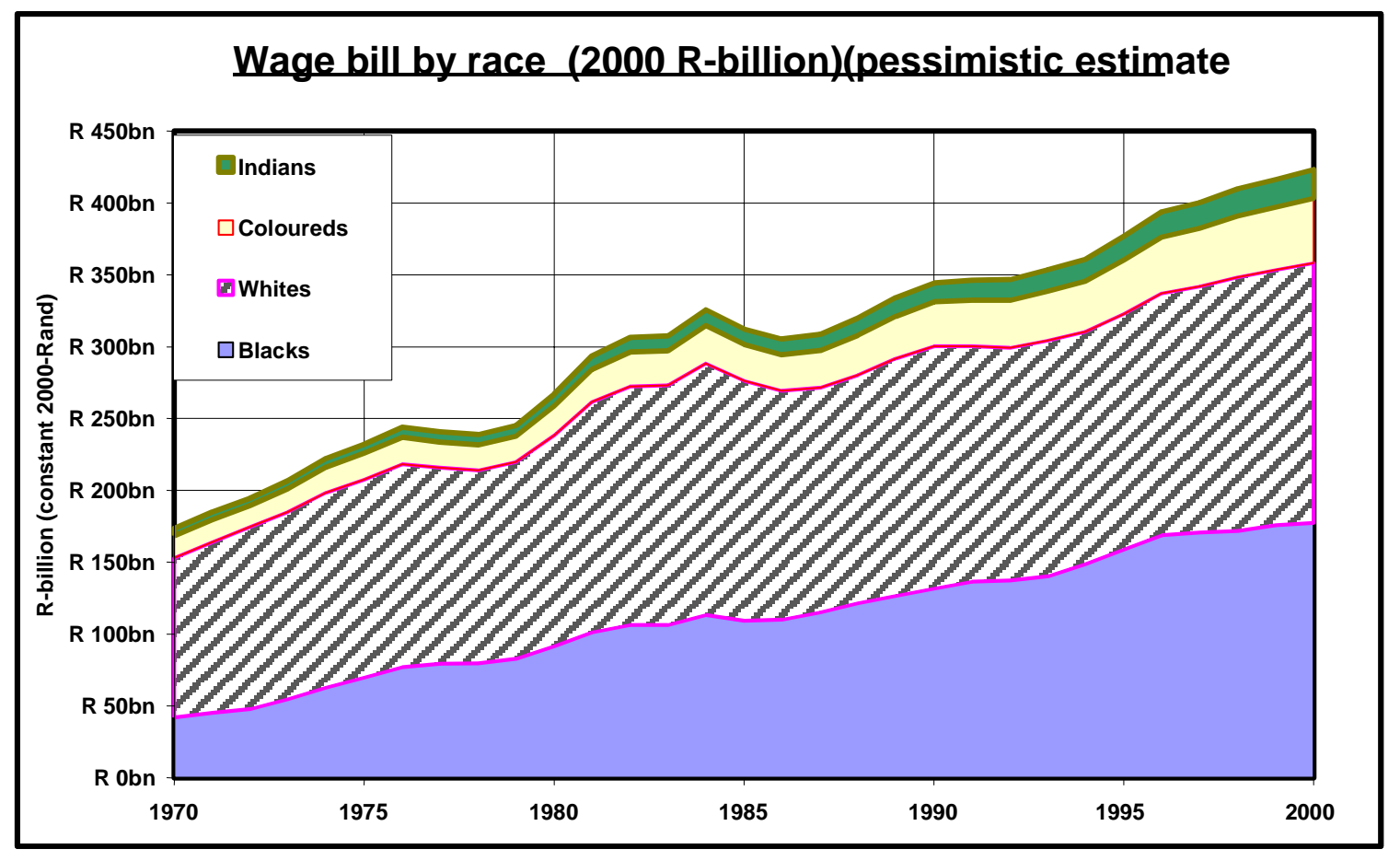

The distribution of transfer income was obtained from data on social grants (social pensions, disability grants, child grants, etc.) collected by the Department of Social Development and its predecessors. As with wages, little racial data is available after the mid-90s, but sufficient information was gleaned from various surveys and a study on fiscal incidence for 1993 to 1997 (Van der Berg 2001) to arrive at figures which probably fairly reflect the distribution of transfers across race groups. 
Income from property is the most difficult of the three components to derive from the available data sets. We used intermittent surveys by the Bureau for Market Research from the mid-70s to the mid-1980s as well as data from the various StatsSA surveys for more recent periods to estimate racial shares of the distribution of this component of current income and interpolate and forecast the shares for the years for which we do not have direct information. Note that there is greater uncertainty after 1996. Our estimates, if anything, probably tend to underestimate the black share of income from this source for this recent period.

These estimates of the inter-racial distribution of the three components of current income make it possible to derive estimates of the distribution of all current income. Figure 3 shows the share of blacks (the largest but also poorest race group) in the total population, all the components of current income, and current income itself. In the case of social transfers, means tested targeting has now ensured that blacks get more than their population share of social grant spending, even before full implementation of the child support grant has taken place. But blacks have a far smaller share in remuneration and particularly property income, even though in both these cases the share is rising. Overall, the black income share closely tracked their share in remuneration, which is quite understandable, given the preponderance of the latter in overall current income and the fact that remuneration carries an even larger share in black incomes. But even with conservative assumptions regarding black gains from property income, the nonremuneration components of black income rose substantially over the period from $17 \%$ to $30 \%$ of all black incomes.

In 1971, Spandau (1971: 185) could still write that "the main distinguishable feature of the distribution of income by race is its relative constancy during the 35 year period 1924/25 to 1960." Indeed, this stability in racial income shares continued until about 1970, despite a rapidly rising black share in population. However, the data below shows that the black share of income has approximately doubled since, bringing an end to a period of mainly widening income inequality between whites and blacks. 


\section{Figure 3:}

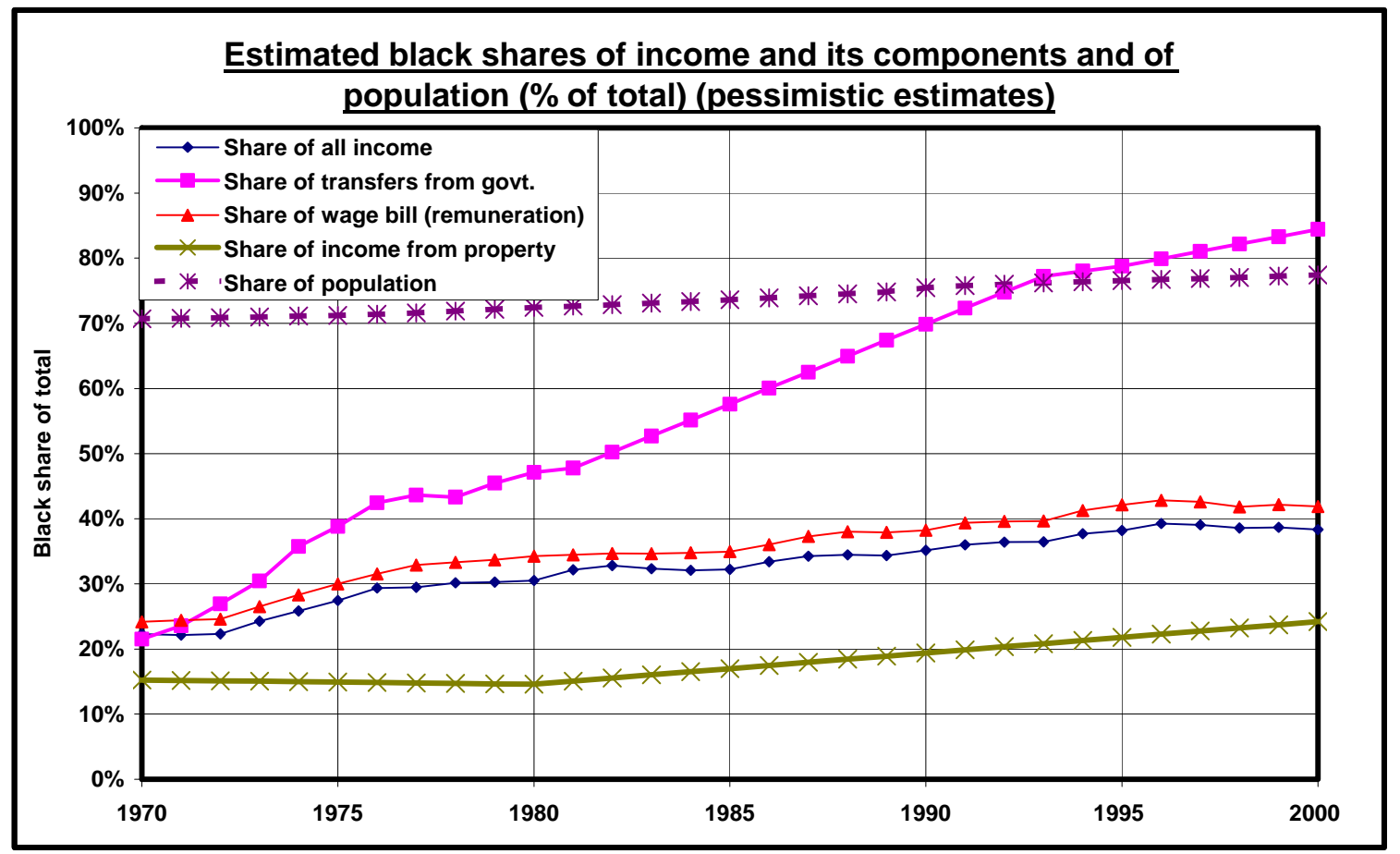

It is now possible to compare these inter-racial income distribution estimates to data obtained from various surveys and censuses by a large variety of authors. ${ }^{5}$ Figure 4 shows the relative per capita income of blacks as a percentage of white levels, a measure of the income gap between the two largest race groups. It is apparent that the IES1995 is quite inconsistent with other survey or census based estimates around this date. Fitting a trend line - a second order polynomial - through these estimates shows a moderately upward trend in relative black per capita incomes, a trend that may have further moderated during the latter part of the 1990s. Alarm about the recent evolution of poverty and inequality referred to earlier was based largely upon comparison of the IES1995 and the IES2000, but these two surveys do not appear to be comparable. Moreover, only $83 \%$ of current income in the National Accounts was captured in the IES2000 versus well above 95\% in IES1995, leading to even more misleading conclusions regarding the path of poverty in this period.

\footnotetext{
${ }^{5}$ Most of these are summarised in Van der Berg \& Bhorat (1999) and in Leibbrandt, Van der Berg \& Bhorat (2001), except for the information from Whiteford \& Van Seventer (2000). For earlier summaries, see also McGrath (1983) \& Spandau (1971).
} 


\section{Figure 4:}

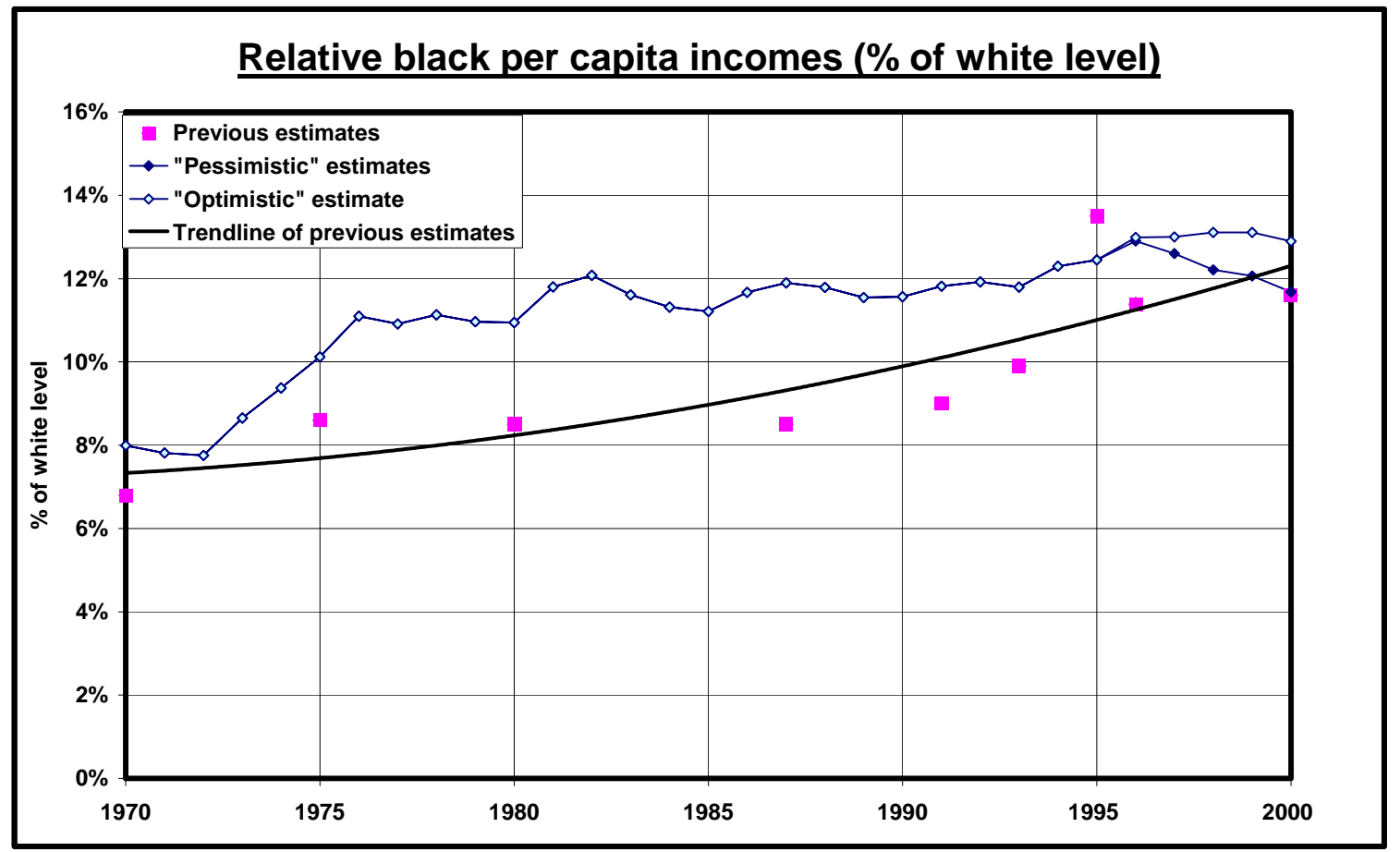

Our own conservative or pessimistic estimates show less upward movement in relative per capita income of blacks than do the previous estimates over the latter part of the period under consideration, but our figures may be underestimates, for reasons discussed below. The estimates derived here show a slightly smaller race gap than estimates based on surveys and censuses - particularly earlier in the period -, which conforms with known evidence of survey underreporting of incomes and expenditures of the poor. Even though our estimated relative black income levels may be somewhat too high, however, the trend derived from our data is both compatible with and also more stable than the intermittent evidence largely derived from household surveys and censuses.

However, our estimates do suffer from some known deficiencies:

- As explained above, the post-1996 data that we used was less dependable in various respects than earlier data, mainly because of the discontinuation of certain data series pertaining to racial wage and employment data after 1996.

- Our black employment estimates for this period are highly conservative: They are based on SA Reserve Bank data on employment trends in mining and the nonprimary sectors respectively, implying job-losses of more than half a million outside of agriculture, whilst for agriculture we assume a continuation of the trend of the previous five years. Bhorat (2003a, 2003b, 2003c), for one, has been very critical of these official employment figures, and indeed StatsSA survey data shows an employment increase outside agriculture of more than 400000 over the same period (see Devey, Skinner \& Valodia 2003: Table 1, p.4).

- Moreover, to be on the conservative side in our estimates of redistribution, we assumed that most employment losses affected blacks rather than other groups. 
- As a second scenario, we also estimated an alternative distribution on less pessimistic employment assumptions, using employment estimates derived from Bhorat (2003c) for the post-1995 period. These estimates are also shown in the figure and referred to as optimistic estimates.

- The rising black share of property income contained in the income series shown in Figure 4 above probably also underestimates the actual trend, due to factors such as black empowerment deals and preferential procurement policies that favoured black entrepreneurs and probably accelerated black access to income earning opportunities of this sort.

Because our data per definition add up to the national accounts magnitudes, the magnitudes of the incomes measured are not as vulnerable to the vagaries associated with survey data as the individual surveys are themselves, usually published or interpreted as they are without adjustment for compatibility with national accounts magnitudes. ${ }^{6}$ As overall real per capita current incomes have been rising strongly, at $1.8 \%$ per annum since 1995, stagnation in black per capita incomes would have required a substantial worsening of inter-racial income distribution - something our estimates, based on conservative assumptions, have shown to be unlikely.

Indeed, Figure 5 confirms a continued though modest rise in black per capita incomes. We can conclude with little fear of contradiction, that black incomes have not regressed between the mid-90s and the year 2000 in real per capita terms, and on the available evidence we have confidence that our estimates are not overly optimistic regarding the path of black per capita incomes.

\footnotetext{
${ }^{6}$ See Deaton (2003 and 2001) for a discussion of how household surveys almost always show much less consumption or consumption growth than national accounts data, implying that this undercount increases over time. This means increasing inaccuracy of household surveys and very limited scope for using surveys for comparison of time trends.
} 


\section{Figure 5:}

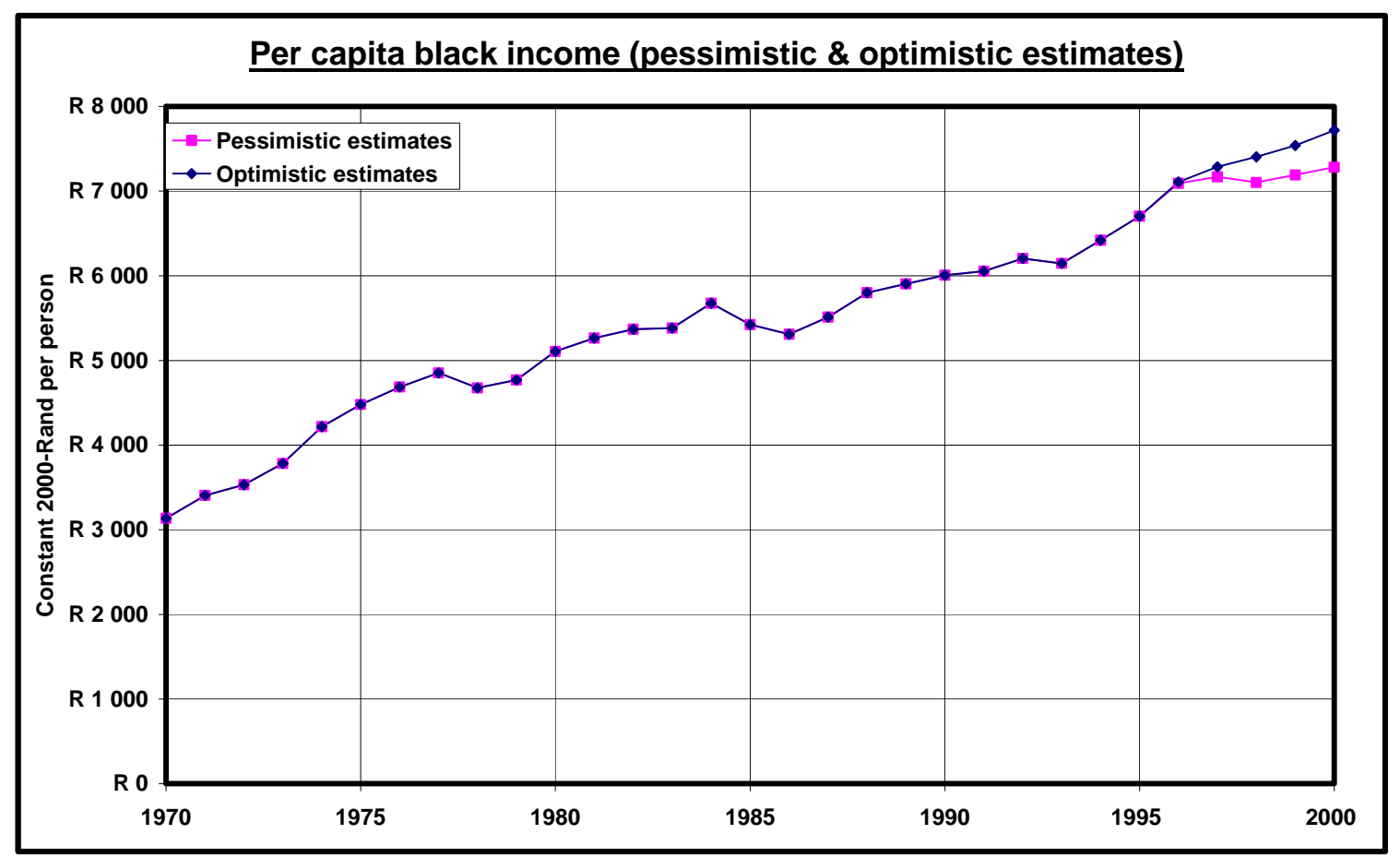

Interestingly, Table 1 shows that the income per capita of all race groups has been growing more rapidly than the national average - an arithmetical quirk brought about by the fact that the poorest race group (blacks) has been experiencing a relative population increase, dragging down average incomes. 
Table 1: Estimates of income and its components, per capita income and population by race, various years

\begin{tabular}{|c|c|c|c|c|c|c|c|c|}
\hline & 1970 & 1975 & 1980 & 1985 & 1990 & 1995 & $\begin{array}{c}\text { 2000: } \\
\text { Pessimistic }\end{array}$ & $\begin{array}{c}\text { 2000: } \\
\text { Optimistic } \\
\end{array}$ \\
\hline \multicolumn{9}{|c|}{ Remuneration (2000 R-million) } \\
\hline Blacks & 41957 & 69760 & 91541 & 109287 & 131737 & 158813 & 177326 & 192441 \\
\hline Coloureds & 15528 & 18479 & 20593 & 25510 & 31145 & 37628 & 45163 & 42240 \\
\hline Indians & 4900 & 6512 & 8401 & 10826 & 13163 & 16601 & 20069 & 21017 \\
\hline Whites & 111135 & 137728 & 146794 & 166952 & 168535 & 163861 & 180832 & 167691 \\
\hline Total & 173519 & 232480 & 267329 & 312574 & 344581 & 376904 & 423390 & 423390 \\
\hline \multicolumn{9}{|c|}{ Transfers from government (2000 R-million) } \\
\hline Blacks & 1574 & 4301 & 5623 & 9215 & 16014 & 20079 & 25228 & 25228 \\
\hline Coloureds & 1077 & 1249 & 1458 & 1860 & 2690 & 2959 & 2832 & 2832 \\
\hline Indians & 286 & 332 & 388 & 494 & 715 & 588 & 598 & 598 \\
\hline Whites & 4379 & 5195 & 4464 & 4430 & 3500 & 1855 & 1222 & 1222 \\
\hline Total & 7316 & 11077 & 11932 & 15999 & 22919 & 25483 & 29880 & 29880 \\
\hline \multicolumn{9}{|c|}{ Income from property (2000 R-million) } \\
\hline Blacks & 6922 & 8621 & 10968 & 14052 & 22878 & 33401 & 49517 & 49517 \\
\hline Coloureds & 908 & 1271 & 1803 & 2066 & 2948 & 3830 & 5115 & 5115 \\
\hline Indians & 1112 & 1516 & 2103 & 2314 & 3302 & 4290 & 5729 & 5729 \\
\hline Whites & 36450 & 46356 & 60246 & 64224 & 88800 & 111694 & 144253 & 144253 \\
\hline Total & 45392 & 57765 & 75120 & 82656 & 117929 & 153215 & 204614 & 204614 \\
\hline \multicolumn{9}{|c|}{ All income (2000 R-million) } \\
\hline Blacks & 50454 & 82683 & 108131 & 132553 & 170630 & 212294 & 252071 & 267185 \\
\hline Coloureds & 17513 & 20999 & 23854 & 29436 & 36784 & 44417 & 53111 & 50188 \\
\hline Indians & 6298 & 8361 & 10892 & 13635 & 17181 & 21480 & 26396 & 27344 \\
\hline Whites & 151963 & 189279 & 211504 & 235605 & 260835 & 277411 & 326307 & 313167 \\
\hline Total & 226228 & 301321 & 354381 & 411230 & 485429 & 555601 & 657884 & 657884 \\
\hline \multicolumn{9}{|c|}{ Per capita income (2000 Rand) } \\
\hline Blacks & 3134 & 4479 & 5107 & 5423 & 6008 & 6704 & 7283 & 7720 \\
\hline Coloureds & 8184 & 8630 & 8822 & 9855 & 11404 & 12722 & 14126 & 13349 \\
\hline Indians & 9595 & 11244 & 13296 & 15113 & 17637 & 20592 & 23938 & 24798 \\
\hline Whites & 39217 & 44242 & 46670 & 48370 & 51951 & 53840 & 62360 & 59849 \\
\hline Total & 9936 & 11626 & 12125 & 12385 & 12903 & 13436 & 14716 & 14716 \\
\hline \multicolumn{9}{|c|}{$\begin{array}{c}\text { Population ('000) } \\
\end{array}$} \\
\hline Blacks & 16097.1 & 18462.1 & 21171.8 & 24442.7 & 28401.3 & 31665.7 & 34609.6 & 34609.6 \\
\hline Coloureds & 2140.0 & 2433.4 & 2704.0 & 2986.9 & 3225.5 & 3491.3 & 3759.8 & 3759.8 \\
\hline \begin{tabular}{|l|} 
Indians \\
\end{tabular} & 656.4 & 743.6 & 819.2 & 902.2 & 974.1 & 1043.1 & 1102.7 & 1102.7 \\
\hline Whites & 3874.9 & 4278.3 & 4531.9 & 4870.9 & 5020.8 & 5152.5 & 5232.6 & 5232.6 \\
\hline Total & 22768.4 & 25917.4 & 29226.0 & 33202.7 & 37621.7 & 41352.6 & 44704.6 & 44704.6 \\
\hline
\end{tabular}


Table 2: Growth of population, real total income and real per capita income by race, 1970-2000 (real income estimates in 2000-Rand)

\begin{tabular}{|c|c|c|c|c|c|c|}
\hline & 1970-80 & $1980-90$ & \multicolumn{2}{|c|}{ 1990-2000 } & \multicolumn{2}{|c|}{ 1970-2000 } \\
\hline \multicolumn{7}{|c|}{ Population: } \\
\hline Blacks & $2.8 \%$ & $3.0 \%$ & \multicolumn{2}{|c|}{$2.0 \%$} & \multicolumn{2}{|c|}{$2.6 \%$} \\
\hline Coloureds & $2.4 \%$ & $1.8 \%$ & \multicolumn{2}{|c|}{$1.5 \%$} & \multicolumn{2}{|c|}{$1.9 \%$} \\
\hline Indians & $2.2 \%$ & $1.7 \%$ & \multicolumn{2}{|c|}{$1.2 \%$} & \multicolumn{2}{|c|}{$1.7 \%$} \\
\hline Whites & $1.6 \%$ & $1.0 \%$ & \multicolumn{2}{|c|}{$0.4 \%$} & \multicolumn{2}{|c|}{$1.0 \%$} \\
\hline Total & $2.5 \%$ & $2.6 \%$ & \multicolumn{2}{|c|}{$1.7 \%$} & \multicolumn{2}{|c|}{$2.3 \%$} \\
\hline & & & $\begin{array}{c}\text { Assuming } \\
\text { pessimistic } \\
2000 \text { estimate }\end{array}$ & $\begin{array}{c}\text { Assuming } \\
\text { optimistic } \\
2000 \text { estimate }\end{array}$ & $\begin{array}{c}\text { Assuming } \\
\text { pessimistic } \\
2000 \text { estimate }\end{array}$ & $\begin{array}{c}\text { Assuming } \\
\text { optimistic } \\
2000 \text { estimate } \\
\end{array}$ \\
\hline \multicolumn{7}{|c|}{ Total income: } \\
\hline Blacks & $7.9 \%$ & $4.7 \%$ & $4.0 \%$ & $4.6 \%$ & $5.5 \%$ & $5.7 \%$ \\
\hline Coloureds & $3.1 \%$ & $4.4 \%$ & $3.7 \%$ & $3.2 \%$ & $3.8 \%$ & $3.6 \%$ \\
\hline Indians & $5.6 \%$ & $4.7 \%$ & $4.4 \%$ & $4.8 \%$ & $4.9 \%$ & $5.0 \%$ \\
\hline Whites & $3.4 \%$ & $2.1 \%$ & $2.3 \%$ & $1.8 \%$ & $2.6 \%$ & $2.4 \%$ \\
\hline Total & $4.6 \%$ & $3.2 \%$ & $3.1 \%$ & $3.1 \%$ & $3.6 \%$ & $3.6 \%$ \\
\hline \multicolumn{7}{|c|}{ Per capita income: } \\
\hline Blacks & $5.0 \%$ & $1.6 \%$ & $1.9 \%$ & $2.5 \%$ & $2.9 \%$ & $3.1 \%$ \\
\hline Coloureds & $0.8 \%$ & $2.6 \%$ & $2.2 \%$ & $1.6 \%$ & $1.8 \%$ & $1.6 \%$ \\
\hline Indians & $3.3 \%$ & $2.9 \%$ & $3.1 \%$ & $3.5 \%$ & $3.1 \%$ & $3.2 \%$ \\
\hline Whites & $1.8 \%$ & $1.1 \%$ & $1.8 \%$ & $1.4 \%$ & $1.6 \%$ & $1.4 \%$ \\
\hline Total & $2.0 \%$ & $0.6 \%$ & $1.3 \%$ & $1.3 \%$ & $1.3 \%$ & $1.3 \%$ \\
\hline
\end{tabular}

It is necessarily more difficult to obtain accurate estimates for the smaller groups, and therefore not too much confidence should be placed in the accuracy of our estimates for coloureds and particularly Indians. Nevertheless, the broad forces at work seem to be well reflected in the estimates shown here.

The fact that the incomes of all race groups have grown does not, however, address the issue of whether poverty has increased. This may well be possible despite such per capita growth, if it is true that inequality has worsened dramatically.

\section{ESTIMATING INTRA-RACIAL (WITHIN GROUP) DISTRIBUTION OF INCOME}

Having obtained estimates of inter-racial distribution of income, we now also require intra-racial distribution data at the individual level to estimate the overall distribution of income. ${ }^{7}$ Because such distributions are slow moving, we can use distribution data from the limited number of surveys and censuses and linearly interpolate from these the intragroup distribution estimates for other years. We used data from various Bureau for Market Research (BMR) surveys, as also utilized by McGrath and the Urban Foundation, as well as the more recent Income and Expenditure Surveys, usually linked to the

\footnotetext{
${ }^{7}$ Distribution data is often expressed in terms of the distribution of households. However, this hides much of the underlying distributional shifts where household size changes. For instance, the comparison by Whiteford \& Van Seventer (2000) of income distribution in the censuses of 1991 and 1996 lose much of its usefulness because household size was largely ignored, despite the fact that they found average household size to have declined by $7 \%$ between the two datasets. This change in household size is not distributed equally across different race and income groups, thus invalidating many of their conclusions on inequality trends.
} 
October Household Surveys, and the Saldru Survey. However, rather than accepting the survey means for these distributions, we use our inter-group estimates, for the reasons already mentioned in the introduction, namely that comparability of these means is severely constrained by various quirks in survey design and sampling as well as varying quality of field work. In spite of these limitations, such surveys give us the best possible source of information on intra-group distribution.

For analysis prior to the mid-90s, official data sources must be augmented by information collected by organisations outside of government. To construct the 1975 income distribution, census data pertaining to whites, coloureds and Asians was combined with data for blacks contained in various Bureau of Market Research (BMR) reports, following McGrath's (1983) approach. Given the limited coverage of the black population by the BMR (particularly in rural areas outside of the homelands), the estimates provided for this group are less reliable than one would like them to be. Population estimates provided by Simkins (1983) were used for 1975 and then adjusted to be in line with a consistent set of population calculations provided by the BMR for the entire period under study (Sadie 1993; Van Aardt \& Van Tonder 1999). Two qualifications to the usefulness of datasets constructed in this manner must be noted: the varying definitions of income across surveys, and the differing income recipient units surveyed (the BMR collects data for households, while the census data relates to families).

The method used to obtain the intra-group distribution is quite simple. We take the frequency distributions of per capita income of all individuals (allocating per capita household income to all individuals in a household) as derived from the surveys, convert the intervals to a $\log$ scale, and then fit Gaussian kernel density functions with a halfbandwidth of 0.40 to this data. ${ }^{8}$ This implicitly assumes a lognormal distribution function as the most likely functional form for the data: this is indeed the function most often fitted to income distribution datasets. Estimating the intra-group distribution in this way follows the method used by Sala-i-Martin (2002a; 2002b) in two important studies published under the auspices of the NBER. He estimated world distribution of income for each year over a period by summing across distributions derived for different countries, after applying Gaussian kernel density fits to quintile distributions of income obtained from survey data by country.

We shift the cumulative density curves derived from the kernel density functions by adjusting the means of these distributions to the mean income per race group that we had estimated earlier. Once we obtain these distribution curves for each of the racial groups, they are weighted by population size and summed across racial groups to arrive at the

\footnotetext{
${ }^{8}$ Sala-i-Martin (2002b) points out that a kernel density function is an approximation to the true density function from observations on the frequency distribution, which does not restrict the country distribution to have a specific functional form. A kernel density function is used to smooth a histogram, in this case of the distribution of individuals across income intervals on a log scale. In his analysis of world income distribution, Sala-i-Martin (2002b) employs a half-bandwidth of 0.35 (his unit of analysis is also the $\log$ of income), whilst Moll (2000), analysing South African wage data, applies a slightly greater level of smoothing by using a half-bandwidth of 0.4 , the same level as ours.
} 
aggregate distribution of the population in each income interval. At this point, the various poverty and inequality measures can be applied to better analyse the data. ${ }^{9}$

Table 4, and the more summarised Table 3, show the estimates we derived of the distribution of income or - where indicated - expenditure, based mainly on survey and census data. For the 1975 estimates, decomposed by region or household type before they were aggregated, we followed as far as possible the methodology employed by McGrath (1983). BMR data for samples of black households in formerly white rural areas, metropolitan areas and homelands was considered representative of the income distribution throughout those regions, and mapped onto the regional population estimates provided by Simkins (1983), excluding blacks in metropolitan areas, for whom the population estimate was calculated as a residual. ${ }^{10}$ In the case of whites, coloureds and Asians, census data for 1970 was projected forwards, allowing for growth in population consistent with the annual estimates provided by the BMR as well as growth in real per capita incomes. As we required deciles composed of equal numbers of individuals rather than households, we also had to estimate household size in those cases where such data was not provided in the original published secondary data sources. Here we used the relationships (expressed in a simple linear regression) between household income and size as contained in other similar datasets to estimate household size.

Note from the data that the estimates obtained for intra-group inequality show a fair degree of consistency, as reflected in the Gini coefficients in Table 3, derived from the various sources. It is unfortunately not possible to distinguish which portion of the differences in the Gini coefficients results from real shifts in distribution and which is due to measurement error. However, as income distribution is slow moving, we can probably discard the 1996 census $^{11}$ as a data source providing comparable data, and the same probably applies to the 1993 expenditure data from the LSDS survey. The results from analysis on both of these datasets are clearly out of line with the broad time trend reflected in each racial income distribution. For 1985, available black income distribution data did not include the rural farm population outside homelands, but as the individual components for various region types seemed suspect, we discarded the 1985 data in any event. ${ }^{12}$ The other data sources are, however, relatively similar in both the magnitude of the Gini coefficients and the shape of the distribution curves (see for instance the Lorenz curves for blacks in Figure 6), thus we accept them as a basis for our further estimates.

\footnotetext{
${ }^{9}$ We use Stata 7 for fitting of the Gaussian kernels the Stata programme, whilst for the analyses of the poverty and inequality trends we made limited use of the programme DAD, a dedicated poverty analysis programme freely made available by the University of Laval in Canada.

${ }^{10}$ No data for blacks in towns was available, so it was assumed that these households received 20 per cent less income than black households in metropolitan areas (given a finding to this effect in BMR Report 65, and the fact that the average household sizes across these regions were similar), assuming the same distributional shape.

${ }^{11}$ Woolard (2001: 40) notes that there was a major undercount of the white population group in this census.

${ }^{12}$ For instance, the Gini for the black non-farm population was 0.49 in 1975 and had risen to 0.61 by 1985 . If these estimates were true, black inequality severely increased from 1975 to 1985, then dropped substantially by 1993, and thereafter again increased. This seems higly unlikely. Thus the 1985 data was not used, leading to a smoother and more usual path of black inequality growth from 1975 tot 1993 that was then continued into the 1990s.
} 
Table 3: Gini coefficients estimated from various surveys and censuses for intragroup distribution (income or expenditure per capita)

\begin{tabular}{|l|c|c|c|c|}
\hline \multicolumn{2}{|c}{ Blacks } & Coloureds & Indians & Whites \\
\hline 1970 &.. & 0.53 & 0.42 & 0.43 \\
\hline 1975 & 0.49 &.. &.. &.. \\
\hline 1993 & 0.56 & 0.47 & 0.50 & 0.47 \\
\hline 1993 (expenditure) & 0.48 & 0.44 & 0.42 & 0.38 \\
\hline 1995 & 0.57 & 0.52 & 0.49 & 0.47 \\
\hline 1995 (expenditure) & 0.58 & 0.52 & 0.49 & 0.47 \\
\hline 1996 & 0.68 & 0.57 & 0.53 & 0.52 \\
\hline 2000 & 0.59 & 0.55 & 0.51 & 0.49 \\
\hline
\end{tabular}

\section{Figure 6:}

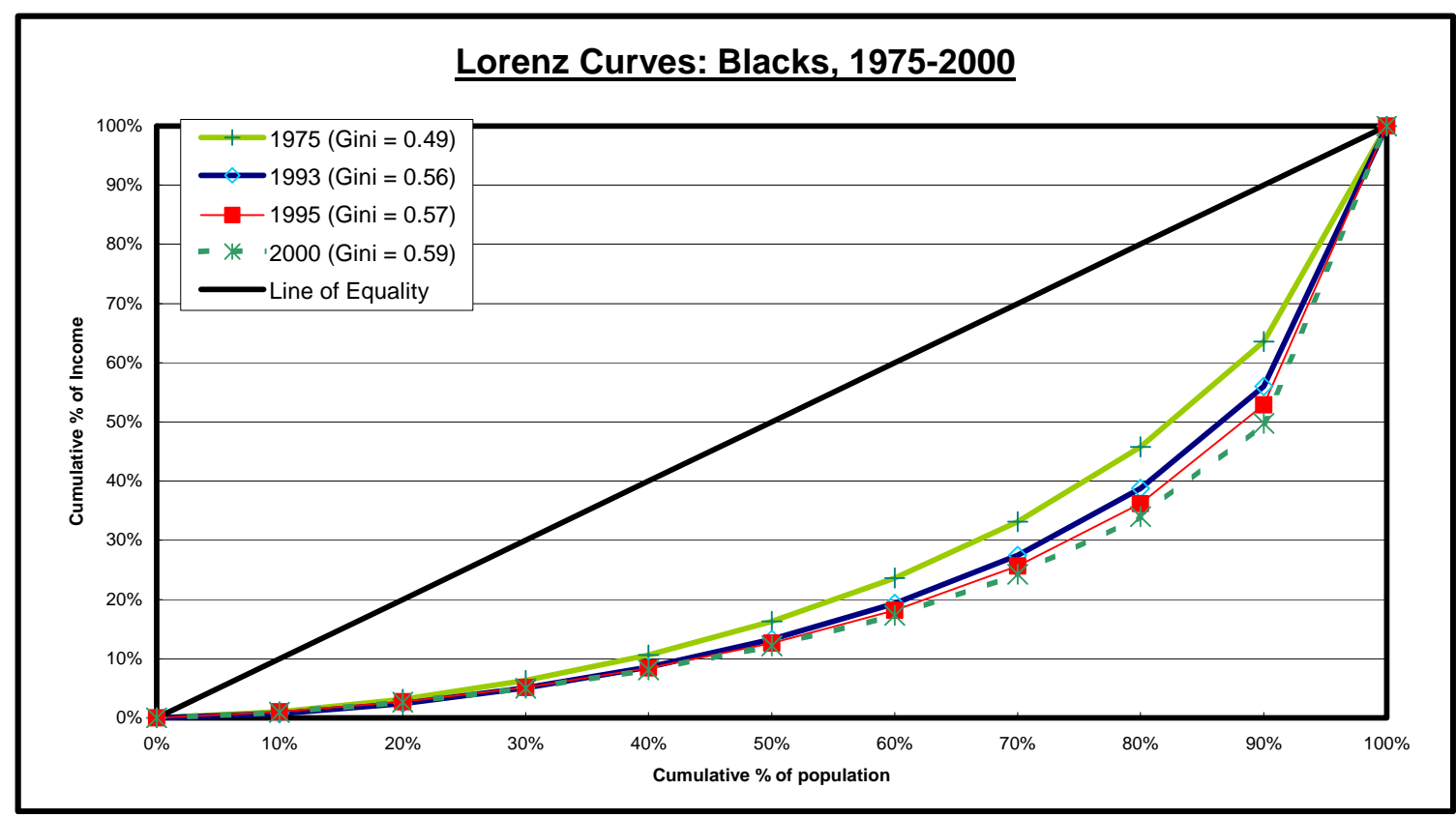

The 1993, 1995 and 2000 surveys show a very similar pattern of within group distribution, with the possible exception of the coloured estimate for 1993. 
Table 4: Cumulative income and population share and Gini coefficient as derived from various data sources by race group and year

\begin{tabular}{|c|c|c|c|c|c|c|c|c|c|c|c|}
\hline & \multicolumn{10}{|c|}{ Decile no: } & \multirow[b]{2}{*}{ Gini } \\
\hline & 1 & 2 & 3 & 4 & 5 & 6 & 7 & 8 & 9 & 10 & \\
\hline \multicolumn{12}{|c|}{ Blacks } \\
\hline - Urban 1975 & $2.5 \%$ & $6.5 \%$ & $11.7 \%$ & $18.0 \%$ & $25.5 \%$ & $34.3 \%$ & $44.7 \%$ & $57.3 \%$ & $73.3 \%$ & $100 \%$ & 0.35 \\
\hline - Towns 1975 & $2.9 \%$ & $7.6 \%$ & $13.5 \%$ & $20.6 \%$ & $28.9 \%$ & $38.3 \%$ & $49.2 \%$ & $61.9 \%$ & $77.5 \%$ & $100 \%$ & 0.30 \\
\hline - Rural 1975 & $2.5 \%$ & $6.5 \%$ & $11.5 \%$ & $17.3 \%$ & $24.0 \%$ & $31.6 \%$ & $40.5 \%$ & $50.8 \%$ & $64.0 \%$ & $100 \%$ & 0.40 \\
\hline - Homeland 1975 & $1.4 \%$ & $3.6 \%$ & $7.0 \%$ & $11.5 \%$ & $17.3 \%$ & $24.6 \%$ & $33.8 \%$ & $46.1 \%$ & $63.7 \%$ & $100 \%$ & 0.48 \\
\hline - Single hholds 1975 & $2.9 \%$ & $7.2 \%$ & $12.6 \%$ & $19.1 \%$ & $26.6 \%$ & $35.6 \%$ & $46.1 \%$ & $58.8 \%$ & $74.7 \%$ & $100 \%$ & 0.33 \\
\hline - Urban (single \& & $2.1 \%$ & $5.5 \%$ & $9.9 \%$ & $15.4 \%$ & $21.9 \%$ & $29.8 \%$ & $39.4 \%$ & $51.5 \%$ & $67.8 \%$ & & 0.41 \\
\hline Total 1975 & $1.0 \%$ & $3.1 \%$ & $6.3 \%$ & $10.6 \%$ & $16.3 \%$ & $23.6 \%$ & $33.2 \%$ & $45.8 \%$ & $63.6 \%$ & $100 \%$ & 0.49 \\
\hline Total excluding rural 1975 & $0.9 \%$ & $2.9 \%$ & $5.9 \%$ & $10.2 \%$ & $15.9 \%$ & $23.5 \%$ & $33.3 \%$ & $46.1 \%$ & $63.9 \%$ & $100 \%$ & 0.49 \\
\hline - Urban 1985 & $1.6 \%$ & $4.9 \%$ & $9.3 \%$ & $14.8 \%$ & $21.6 \%$ & $29.8 \%$ & $39.7 \%$ & $52.0 \%$ & $68.1 \%$ & $100 \%$ & 0.42 \\
\hline - Towns 1985 & $2.1 \%$ & $6.1 \%$ & $11.2 \%$ & $17.4 \%$ & $24.9 \%$ & $33.8 \%$ & $44.5 \%$ & $57.5 \%$ & $73.9 \%$ & $100 \%$ & 0.36 \\
\hline - Homeland 1985 & $0.4 \%$ & $1.5 \%$ & $3.2 \%$ & $5.7 \%$ & $9.0 \%$ & $13.5 \%$ & $19.6 \%$ & $28.0 \%$ & $42.3 \%$ & $100 \%$ & 0.65 \\
\hline - Single households 1985 & $1.9 \%$ & $5.7 \%$ & $10.7 \%$ & $16.8 \%$ & $24.0 \%$ & $32.7 \%$ & $42.9 \%$ & $55.3 \%$ & $71.3 \%$ & & 0.38 \\
\hline Total excluding Rural 1985 & $0.5 \%$ & $1.8 \%$ & $3.8 \%$ & $6.9 \%$ & $10.9 \%$ & $16.4 \%$ & $23.5 \%$ & $33.5 \%$ & $50.2 \%$ & $100 \%$ & 0.61 \\
\hline 1993 & $0.7 \%$ & $2.4 \%$ & $5.0 \%$ & $8.6 \%$ & $13.3 \%$ & $19.4 \%$ & $27.5 \%$ & $38.8 \%$ & $56.0 \%$ & $100 \%$ & 0.56 \\
\hline 1993 (expenditure) & $1.5 \%$ & $4.2 \%$ & $7.8 \%$ & $12.3 \%$ & $18.0 \%$ & $25.2 \%$ & $34.1 \%$ & $45.9 \%$ & $62.6 \%$ & $100 \%$ & 0.48 \\
\hline 1995 & $1.0 \%$ & $2.7 \%$ & $5.2 \%$ & $8.4 \%$ & $12.7 \%$ & $18.2 \%$ & $25.7 \%$ & $36.2 \%$ & $52.9 \%$ & $100 \%$ & 0.57 \\
\hline 1995 (expenditure) & $1.0 \%$ & $2.7 \%$ & $5.1 \%$ & $8.3 \%$ & $12.5 \%$ & $18.1 \%$ & $25.5 \%$ & $36.1 \%$ & $52.8 \%$ & $100 \%$ & 0.58 \\
\hline 1996 & $0.3 \%$ & $1.0 \%$ & $2.1 \%$ & $4.0 \%$ & $6.8 \%$ & $10.9 \%$ & $17.1 \%$ & $26.8 \%$ & $43.3 \%$ & $100 \%$ & 0.68 \\
\hline 2000 & $0.9 \%$ & $2.6 \%$ & $5.0 \%$ & $8.1 \%$ & $12.1 \%$ & $17.3 \%$ & $24.2 \%$ & $34.0 \%$ & $49.8 \%$ & $100 \%$ & 0.59 \\
\hline \multicolumn{12}{|c|}{ Coloureds } \\
\hline 1970 & $0.6 \%$ & $2.3 \%$ & $5.1 \%$ & $9.0 \%$ & $14.3 \%$ & $21.3 \%$ & $30.5 \%$ & $43.1 \%$ & $61.3 \%$ & $100 \%$ & 0.53 \\
\hline 1993 & $1.2 \%$ & $3.7 \%$ & $7.3 \%$ & $12.1 \%$ & $18.1 \%$ & $25.6 \%$ & $35.1 \%$ & $47.5 \%$ & $64.8 \%$ & $100 \%$ & 0.47 \\
\hline 1993 (expenditure) & $1.8 \%$ & $4.8 \%$ & $8.8 \%$ & $14.0 \%$ & $20.4 \%$ & $28.2 \%$ & $37.8 \%$ & $50.0 \%$ & $66.5 \%$ & $100 \%$ & 0.44 \\
\hline 1995 & $1.2 \%$ & $3.4 \%$ & $6.5 \%$ & $10.5 \%$ & $15.7 \%$ & $22.3 \%$ & $30.8 \%$ & $42.2 \%$ & $58.9 \%$ & $100 \%$ & 0.52 \\
\hline 1995 (expenditure) & $1.2 \%$ & $3.4 \%$ & $6.4 \%$ & $10.3 \%$ & $15.3 \%$ & $21.7 \%$ & $30.1 \%$ & $41.3 \%$ & $57.9 \%$ & $100 \%$ & 0.52 \\
\hline 1996 & $0.5 \%$ & $1.9 \%$ & $4.3 \%$ & $7.7 \%$ & $12.3 \%$ & $18.4 \%$ & $26.7 \%$ & $38.1 \%$ & $55.6 \%$ & $100 \%$ & 0.57 \\
\hline 2000 & $1.0 \%$ & $2.8 \%$ & $5.4 \%$ & $8.9 \%$ & $13.4 \%$ & $19.4 \%$ & $27.4 \%$ & $38.8 \%$ & $56.5 \%$ & $100 \%$ & 0.55 \\
\hline \multicolumn{12}{|c|}{ Indians } \\
\hline 1970 & $1.2 \%$ & $3.9 \%$ & $8.0 \%$ & $13.4 \%$ & $20.2 \%$ & $28.8 \%$ & $39.5 \%$ & $53.1 \%$ & $71.1 \%$ & $100 \%$ & 0.42 \\
\hline 1993 & $1.2 \%$ & $3.6 \%$ & $7.0 \%$ & $11.4 \%$ & $16.9 \%$ & $23.8 \%$ & $32.7 \%$ & $44.3 \%$ & $60.4 \%$ & $100 \%$ & 0.50 \\
\hline 1993 (expenditure) & $2.1 \%$ & $5.5 \%$ & $9.9 \%$ & $15.2 \%$ & $21.6 \%$ & $29.3 \%$ & $38.7 \%$ & $50.5 \%$ & $66.6 \%$ & $100 \%$ & 0.42 \\
\hline 1995 & $1.4 \%$ & $3.9 \%$ & $7.4 \%$ & $11.8 \%$ & $17.3 \%$ & $24.2 \%$ & $32.8 \%$ & $44.0 \%$ & $59.9 \%$ & $100 \%$ & 0.49 \\
\hline 1995 (expenditure) & $1.5 \%$ & $4.1 \%$ & $7.7 \%$ & $12.2 \%$ & $17.8 \%$ & $24.8 \%$ & $33.5 \%$ & $44.7 \%$ & $60.8 \%$ & $100 \%$ & 0.49 \\
\hline 1996 & $0.6 \%$ & $2.5 \%$ & $5.4 \%$ & $9.4 \%$ & $14.6 \%$ & $21.3 \%$ & $30.1 \%$ & $41.8 \%$ & $58.8 \%$ & $100 \%$ & 0.53 \\
\hline 2000 & $1.3 \%$ & $3.5 \%$ & $6.7 \%$ & $10.8 \%$ & $16.0 \%$ & $22.8 \%$ & $31.5 \%$ & $43.3 \%$ & $60.8 \%$ & $100 \%$ & 0.51 \\
\hline \multicolumn{12}{|c|}{ Whites } \\
\hline 1970 & $1.5 \%$ & $4.8 \%$ & $9.1 \%$ & $14.5 \%$ & $21.0 \%$ & $28.9 \%$ & $38.3 \%$ & $49.9 \%$ & $65.5 \%$ & $100 \%$ & 0.43 \\
\hline 1993 & $1.4 \%$ & $4.2 \%$ & $8.0 \%$ & $12.8 \%$ & $18.7 \%$ & $26.0 \%$ & $35.0 \%$ & $46.4 \%$ & $62.2 \%$ & $100 \%$ & 0.47 \\
\hline 1993 (expenditure) & $2.3 \%$ & $6.0 \%$ & $10.9 \%$ & $16.8 \%$ & $23.8 \%$ & $32.1 \%$ & $42.1 \%$ & $54.3 \%$ & $70.1 \%$ & $100 \%$ & 0.38 \\
\hline 1995 & $1.4 \%$ & $4.1 \%$ & $7.8 \%$ & $12.5 \%$ & $18.4 \%$ & $25.7 \%$ & $34.8 \%$ & $46.3 \%$ & $62.2 \%$ & $100 \%$ & 0.47 \\
\hline 1995 (expenditure) & $1.4 \%$ & $4.2 \%$ & $8.0 \%$ & $12.8 \%$ & $18.7 \%$ & $26.1 \%$ & $35.2 \%$ & $46.7 \%$ & $62.7 \%$ & $100 \%$ & 0.47 \\
\hline 1996 & $0.6 \%$ & $2.5 \%$ & $5.6 \%$ & $9.8 \%$ & $15.3 \%$ & $22.3 \%$ & $31.2 \%$ & $43.0 \%$ & $59.7 \%$ & $100 \%$ & 0.52 \\
\hline 2000 & $1.3 \%$ & $3.7 \%$ & $7.2 \%$ & $11.7 \%$ & $17.4 \%$ & $24.5 \%$ & $33.4 \%$ & $44.9 \%$ & $61.0 \%$ & $100 \%$ & 0.49 \\
\hline
\end{tabular}




\section{POVERTY: WHAT THE DATA TELL US}

Accepting the distribution from the 1970s (1975 for blacks, 1970 for other groups) and also those for 1993, 1995 and 2000, it is possible to interpolate the Lorenz curves for years in between, or to project the 1975 black distribution backward. Performing this operation assumes that inequality follows a relatively smooth time path. This assumption allows us to estimate overall distributional inequality and also poverty at any given poverty line for each race groups (and thus also for the country as a whole) for any year within this period, once the intra-group distribution is applied to the estimated group mean income. The poverty line used is R3000 per capita per year in 2000 currency value, to broadly accord with the lines used by Woolard \& Leibbrandt (2001: Table 2.5).

Table 5 summarises our results for five-yearly intervals (the 1993 data is also shown because it is one of our anchor dates). According to these estimates, poverty declined sharply in the 1970s, particularly during the first half of that decade. This is quite understandable, given the rapid growth rate achieved until 1975 and the rapid rise in black wages that occurred in that period. The poverty headcount ratio has remained largely unchanged from the mid-80s, with more recent movement cancelling out an initial improvement. This indicates that the net effect of rising per capita incomes for all race groups has just cancelled the effect of rising inequality in most groups, though the headcount itself has increased quite markedly as a result of population increase. This conclusion, however, could be more optimistic if black incomes have grown more rapidly than we have estimated, which as we have indicated may be quite possible. Thus we may conclude that money-metric poverty, in terms of the headcount ratio, has changed very little in the last decade and a half, despite worsening within group inequality. A somewhat more optimistic reading of the evidence, applying the same intra-racial distributions to the optimistic racial per capita income data discussed before, is also presented in the table and shows that indeed the headcount poverty ratio could perhaps have declined by almost $2 \frac{1}{2} 2$ percentage points in the latter part of this period. 
Table 5: Estimates of poverty headcount and poverty headcount ratio by race, selected years from 1970 to 2000 (poverty line at R3 000 per capita per annum)

\begin{tabular}{|c|c|c|c|c|c|}
\hline & Blacks & Coloureds & Indians & Whites & Total \\
\hline \multicolumn{6}{|c|}{ Poverty headcount ratio (\% in poverty): } \\
\hline 1970 & $64.6 \%$ & $34.1 \%$ & $17.9 \%$ & $2.7 \%$ & $49.8 \%$ \\
\hline 1975 & $52.9 \%$ & $30.2 \%$ & $15.3 \%$ & $2.3 \%$ & $43.7 \%$ \\
\hline 1980 & $49.3 \%$ & $28.3 \%$ & $12.5 \%$ & $2.1 \%$ & $38.9 \%$ \\
\hline 1985 & $49.1 \%$ & $22.9 \%$ & $10.6 \%$ & $1.8 \%$ & $38.8 \%$ \\
\hline 1990 & $45.9 \%$ & $17.4 \%$ & $8.7 \%$ & $1.5 \%$ & $35.3 \%$ \\
\hline 1993 & $48.0 \%$ & $14.8 \%$ & $7.8 \%$ & $1.5 \%$ & $38.2 \%$ \\
\hline 1995 & $48.4 \%$ & $17.3 \%$ & $5.2 \%$ & $1.2 \%$ & $38.8 \%$ \\
\hline 2000: Pessimistic & $47.4 \%$ & $19.0 \%$ & $4.7 \%$ & $1.4 \%$ & $38.6 \%$ \\
\hline 2000: Optimistic & $44.4 \%$ & $21.0 \%$ & $4.3 \%$ & $1.4 \%$ & $36.4 \%$ \\
\hline $\begin{array}{l}\text { 2000: Pessimistic, with } \\
\text { intra-race inequality as in } \\
1970\end{array}$ & $31.7 \%$ & $19.4 \%$ & $5.8 \%$ & $1.9 \%$ & $26.5 \%$ \\
\hline \multicolumn{6}{|c|}{ Poverty headcount ratio (number in poverty): } \\
\hline 1970 & 10397430 & 729291 & 117653 & 103391 & 11349734 \\
\hline 1975 & 9761669 & 735241 & 735241 & 99401 & 11333527 \\
\hline 1980 & 10427844 & 735241 & 102322 & 93716 & 11361103 \\
\hline 1985 & 12003438 & 685275 & 95828 & 87997 & 12874522 \\
\hline 1990 & 13026970 & 85024 & 85024 & 76652 & 13273670 \\
\hline 1993 & 14614503 & 502091 & 79107 & 74008 & 15269709 \\
\hline 1995 & 15311490 & 605010 & 54638 & 62810 & 16033948 \\
\hline 2000: Pessimistic & 16400691 & 713164 & 51971 & 73885 & 17239710 \\
\hline 2000: Optimistic & 15351339 & 788548 & 47947 & 73459 & 16261294 \\
\hline $\begin{array}{l}\text { 2000: Pessimistic, with } \\
\text { intra-race inequality as in } \\
1970\end{array}$ & 10958246 & 730475 & 64227 & 98451 & 11853368 \\
\hline
\end{tabular}

As a counterfactual, we also estimated what poverty would have been if 1970 intra-race inequality had remained unchanged at 1970 levels, combined with the pessimistic path of inter-race inequality. Aggregate poverty would have declined from $49.8 \%$ in 1970 to $26.5 \%$ rather than $38.6 \%$ in 2000 . Growing intra-black inequality in particular had a high price in terms of poverty outcomes, but still could not prevent a reduction in aggregate poverty.

While the focus in this paper has been on money-metric poverty, this does not detract from the fact that other factors also play an important role in poverty. Earlier work has shown that increasing resources have been made available to the poor by the state, leading to an improvement in other aspects of their socio-economic situation since the political transition, despite poor service delivery and particularly concerns regarding the quality of services (e.g. education and health) available to the poor (Van der Berg \& Burger 2003).

\section{CONCLUSION}

Rising black per capita incomes over the past three decades have narrowed the interracial income gap, although increasing inequality within the black population seems to have prevented a significant decline in aggregate inequality and poverty in the latter part 
of this period. But analysis also reveals that it is unlikely that rising intra-racial inequality has been sufficiently large to increase the proportion of the population living in poverty, given the upward trend in per capita incomes. At least by money-metric measures, poverty appears to have been relatively stable in terms of the poverty headcount and using a poverty line of R3 000 per capita per year (2000 Rand values). The number in poverty has increased only because of a growing population.

This paper has shown that a more complete picture of the course of inter-racial income distribution is possible by estimating racial shares of the three major components of current income. Using this method is associated with the advantages over surveys that results arrived at are more directly comparable, and in particular that they agree with national accounts magnitudes. However, the quality of the data is weaker after 1996, because of the failure to continue collecting certain race-based data series, and further work is required to improve the post-1996 estimates. As indicated, however, any revision is likely to be more optimistic than our original pessimistic estimates about narrowing of the racial income gap, given the assumptions we have made.

Obtaining intra-racial distribution data which is comparable across time remains more problematical, particularly for earlier periods where only published data from surveys rather than individual data records were available. Nevertheless, we believe that the method applied here yields good returns and the data series can be expanded as more survey data becomes available. Thus while our final conclusions still use surveys, their use is confined to providing a picture of inequality within race groups. 


\section{BIBLIOGRAPHY}

Bhalla, Surjit. 2002. Imagine there's no country: Poverty, inequality and growth in the era of globalization. Washington, D.C.: Institute for International Economics

Bhorat, Haroon. 2003a. Employment, earnings and vulnerability in the South African labour market: An empirical investigation based on official survey data. Unpublished PhD-Thesis. Stellenbosch: University of Stellenbosch.

Bhorat, Haroon. 2003b. The post-apartheid challenge: Labour demand trends in the South African labour market, 1995-1999. DPRU Working Paper 03/82. Cape Town: Development Policy Research Unit.

Bhorat, Haroon. 2003c. Labour market challenges in the post-apartheid South Africa. Mimeo. Cape Town: Development Policy Research Unit.

Bhorat, Haroon; Murray Leibbrandt; Muzi Maziya; Servaas van der Berg; \& Ingrid Woolard,. 2001. Fighting poverty: Labour markets and inequality in South Africa. UCT Press: Cape Town.

Bourguignon, Francois \& Morrisson, Christian. 2002. Inequality among world citizens: 1820-1992. American Economic Review 92(4): 727-44

Bureau of Market Research. Report No's 31, 50.1, 50.2, 50.3, 50.4, 50.10, 50.11, 50.13, 50.15, 64, 65, 66, 82, 90, 113, 117, 128, 130.1-130.19, 143, 151, 163, 188. Pretoria: BMR, University of South Africa.

Deaton, Angus. 2001. Counting the world's poor: Problems and possible solutions. World Bank Research Observer 16(2): 125-148

Deaton, Angus. 2003. Measuring poverty in a growing world (or measuring growth in a poor world). NBER Working Paper 9822. Cambridge, Mass.: National Bureau for Economic Research.

Devey, Richard; Skinner, Caroline; \& Valodia, Imraan. 2003. Informal economy employment data in South Africa: A critical analysis. Paper to the TIPS/DPRU Forum. Johannesburg. 8-10 September.

Klasen, Stephan \& Woolard, Ingrid. 1999. Levels, trends and consistency of employment and unemployment figures in South Africa. Development Southern Africa 16(1): 1999: 3-35.

Leibbrandt, Murray; Van der Berg, Servaas; \& Bhorat, Haroon. 2001. "Introduction.” In: Leibbrandt, Murray; Maziya, Muzi; Van der Berg, Servaas; \& Woolard, Ingrid (eds.). 2001. Fighting poverty: Labour markets and inequality in South Africa. UCT Press: Lansdowne: 1-20.

Leibbrandt, M \& Woolard, I. 1999. A comparison of poverty in South Africa's nine provinces. Development Southern Africa 16(1).

Leibbrandt, M., Woolard, I. and Bhorat, H. 2000. Understanding contemporary household inequality in South Africa. Studies in Economics and Econometrics 24(3): 31-52.

Leibbrandt, M; Woolard, C; \& Woolard, I 1996. The contribution of income components to income inequality in South Africa. LSMS Working Paper 125. Washington, D.C.: World Bank

May, Julian (ed.). 2000. Poverty and inequality in South Africa: Meeting the challenge. David Philip: Cape Town. 
McGrath, Michael D. 1983. The distribution of personal income in South Africa in selected years over the period from 1945 to 1980. Ph.D. thesis. Durban: University of Natal.

McGrath, Michael D. \& Whiteford, Andrew. 1994. Inequality in the size distribution of income in South Africa. Occasional Papers 10, Stellenbosch: Stellenbosch Economic Project.

Moll, P. 2000. Discrimination is declining in South Africa but inequality is not. Studies in Economics \& Econometrics 24(3): 91-109.

Nattrass, Jill. 1977. Narrowing wage differentials and income distribution in South Africa. South African Journal of Economics 45(4).

Poverty and Inequality Report. 1998. Poverty and inequality in South Africa. Report prepared for the Office of the Executive Deputy President and the InterMinisterial Committee for Poverty and Inequality. Pretoria: Government Printer.

Quah, Danny. 2002. One third of the world's growth and inequality. Wider Discussion Paper 2002/38. Helsinki: World Institute for Development Economics Research (Wider), United Nations University.

Ravallion, Martin. 2001. Comment on "Counting the world's poor", by Angus Deaton. World Bank Research Observer 16(2): 149-156.

Ravallion, Martin. 2002. Have we already met die millennium development goal for poverty? Washington, D.C.: World Bank. Available: http://poverty.worldbank. org/files/12978_Have_we_already_met_the_MDG_Ravallion_response_to_ Bhalla.pdf

RDP Office (1995), Key Indicators of Poverty in South Africa, Pretoria: RDP office

Roukens de Lange, A. \& Van Eeghen, P.H. 1984. Employment in South Africa: evaluation and trend analysis. Report to the National Manpower Commission. Stellenbosch: Institute for Futures Research.

Roukens de Lange, A. \& Van Eeghen, P.H. 1990. Standardised employment series for South Africa's formal economy. Studies in Economics and Econometrics 14(2).

Sadie, J.L. 1993. A projection of the South African population, 1991-2011. Bureau of Market Research, Research Report No.195. Pretoria: University of South Africa.

Sala-i-Martin, Xavier. 2002a. The world distribution of income (estimated from individual country distributions). NBER Working Paper No. 8933. Cambridge, Mass.: National Bureau for Economic Research.

Sala-i-Martin, Xavier. 2002b. The disturbing "rise" of world income inequality. NBER Working Paper 8904. Cambridge, Mass.: National Bureau for Economic Research.

Saldru. 1994. South Africans rich and poor: Baseline household statistics. Cape Town: Saldru.

Simkins, Charles. 1998. On the durability of South African inequality. Macarthur Foundation Working Paper. Princeton: Macarthur Network on Inequality and Poverty

Simkins, Charles. 1991. The Urban Foundation income distribution model: Phase One. Mimeo. Johannesburg: Urban Foundation.

Simkins, Charles. 1983. Four essays on the past, present and possible future of the distribution of the black population of South Africa. Cape Town: Saldru. 
Simkins, Charles. 1979. The distribution of personal income among income recipients in South Africa, 1970 and 1976. Durban: University of Natal.South Africa, Central Statistical Service. 1970. Population Census 1970. Pretoria: Government Printer.

South Africa, Central Statistical Service. 1985. Report No. 01-11-02 (1985): Survey of household expenditure. Pretoria: Government Printer.

South Africa, Central Statistical Service 1996. October household survey 1995. Statistical Release P0317. Pretoria: Central Statistical Service

South Africa, Central Statistical Service. 1997. Earning and spending in South Africa. Selected findings of the 1995 income and expenditure survey. Pretoria: Central Statistical Service.

South Africa, Central Statistical Services. 1998a. Living in South Africa: Selected findings of the 1995 October household survey. Pretoria: Central Statistical Services

South Africa, Central Statistical Service/Statistics South Africa. Various years. South African labour statistics. Pretoria: Government Printer.

South Africa, Central Statistical Service/Statistics South Africa. Various years. South African statistics. Pretoria: Government Printer.

South Africa, Central Statistical Service/Statistics South Africa. 2002. Earning and spending in South Africa. Selected findings and comparisons from the income and expenditure surveys of October 1995 and October 2000. Pretoria: Statistics South Africa

South African Institute of Race Relations (Various years). South Africa Survey (formerly Race Relations Survey). Johannesburg: South African Institute of Race Relations.

Spandau, A.M.K.M. 1971. Income distribution and economic growth in South Africa. Doctoral thesis. Pretoria: University of South Africa.

Terreblanche, Sampie. 2002. A history of inequality in South Africa, 1652-2002. Pietermaritzburg: University of Natal Press

Van Aardt, CJ \& Van Tonder, JL. 1999. A projection of the South African population, 1996-2021. Bureau of Market Research, Research Report No.270. Pretoria: University of South Africa.

Van der Berg, Servaas. 1986. Forecasts of interracial income distribution to the year 2000. Stellenbosch: Institute for Futures Research.

Van der Berg, Servaas. 1987. Die verband tussen die aard en omvang van ekonomiese groei en die bevrediging van basiese behoeftes in Suid-Afrika. Unpublished Ph.D.-thesis. Stellenbosch: University of Stellenbosch

Van der Berg, Servaas. 1989a. On inter-racial income distribution in South Africa. South African Journal of Economics 57(1)

Van der Berg, Servaas. 1989b. Long term economic trends and development prospects in South Africa. African Affairs 88(351): 187-203.

Van der Berg, Servaas. 2001. Redistribution through the budget: Public expenditure incidence in South Africa. Social Dynamics 27(1):140-164

Van der Berg, Servaas \& Bhorat, Haroon. The present as a legacy of the past: The labour market, inequality, and poverty in South Africa. DPRU Working Paper no. 99/29. Cape Town: DPRU.

Van der Berg, Servaas \& Burger, Ronelle. 2002. The stories behind the numbers: An investigation of efforts to deliver services to the South African poor. Background 
report for the World Bank's World Development Report. Mimeo. Stellenbosch: University of Stellenbosch.

Whiteford, A. \& McGrath, M. 1994. The distribution of income in South Africa. Pretoria: Human Sciences Research Council

Whiteford, A. \& Van Seventer, DE. 2000. South Africa's changing income distribution in the 1990s. Studies in Economics \& Econometrics 24(3): 7-30

Whiteford, A.; Posel, D.; \& Kelawang, T. 1995. A profile of poverty, inequality and human development. Pretoria: Human Sciences Research Council.

Woolard, I. 2001. Income inequality and poverty: methods of estimation and some policy applications for South Africa. PhD thesis. Cape Town: University of Cape Town.

Woolard, Ingrid \& Leibbrandt, Murray. 2001. Measuring poverty in South Africa. Ch.2 in: Bhorat, Haroon; Murray Leibbrandt; Muzi Maziya; Servaas van der Berg; \& Ingrid Woolard. 2001. Fighting poverty: Labour markets and inequality in South Africa. Cape Town: UCT Press: 41-73 